\title{
Expression and Functional Roles of Bradyrhizobium japonicum Genes Involved in the Utilization of Inorganic and Organic Sulfur Compounds in Free-Living and Symbiotic Conditions
}

\author{
Masayuki Sugawara, ${ }^{1}$ Gopit R. Shah, ${ }^{2}$ Michael J. Sadowsky, ${ }^{1}$ Oleg Paliy, ${ }^{3}$ Justin Speck, ${ }^{2}$ Andrew W. Vail, ${ }^{1}$ \\ and Prasad Gyaneshwar ${ }^{2}$ \\ ${ }^{1}$ Department of Soil Water and Climate, University of Minnesota, St. Paul, U.S.A.; ${ }^{2}$ Department of Biological Sciences, \\ University of Wisconsin, Milwaukee, U.S.A.; and ${ }^{3}$ Department of Biochemistry and Molecular Biology, Wright State \\ University, Dayton OH, U.S.A.
}

Submitted 13 August 2010. Accepted 14 December 2010.

\begin{abstract}
Strains of Bradyrhizobium spp. form nitrogen-fixing symbioses with many legumes, including soybean. Although inorganic sulfur is preferred by bacteria in laboratory conditions, sulfur in agricultural soil is mainly present as sulfonates and sulfur esters. Here, we show that Bradyrhizobium japonicum and $B$. elkanii strains were able to utilize sulfate, cysteine, sulfonates, and sulfur-ester compounds as sole sulfur sources for growth. Expression and functional analysis revealed that two sets of gene clusters (bll6449 to bll6455 or bll7007 to bll7011) are important for utilization of sulfonates sulfur source. The bll6451 or bll7010 genes are also expressed in the symbiotic nodules. However, $B$. japonicum mutants defective in either of the sulfonate utilization operons were not affected for symbiosis with soybean, indicating the functional redundancy or availability of other sulfur sources in planta. In accordance, $B$. japonicum bacteroids possessed significant sulfatase activity. These results indicate that strains of Bradyrhizobium spp. likely use organosulfur compounds for growth and survival in soils, as well as for legume nodulation and nitrogen fixation.
\end{abstract}

Bacteria assimilate sulfur, an essential element, from various inorganic and organic compounds in the environment. Although bacteria utilize inorganic sulfur (sulfate) for growth in laboratory media, organic sulfur in the form of ester-sulfur and sulfonates constitute approximately $95 \%$ of the total sulfur in aerobic soils (Autry and Fitzgerald 1990). The detailed molecular mechanisms for sulfonate sulfur utilization (ssu) has been determined in the gram-negative bacteria Escherichia coli (van der Ploeg et al. 2001), Pseudomonas aeruginosa (Kertesz 1999), P. putida (Kahnert et al. 2000; Mirleau et al. 2005), and Burkholderia cenocepacia (Iwanika-Nowicka et al. 2007), as well as in the gram-positive bacteria Bacillus subtilis (van der Ploeg et al. 1998) and Corynebacterium glutamicum (Koch et

M. Sugawara and G. R. Shah contributed equally to this work.

Corresponding author: P. Gyaneshwar; Telephone: +1.414.229.4363; Fax: +1.414.229.3926; E-mail: prasadg@uwm.edu

* The $\boldsymbol{e}$-Xtra logo stands for "electronic extra" and indicates that seven supplementary tables are published online. al. 2005). The ssu genes, that encode $\mathrm{ABC}$ transport proteins $(s s u A B C)$ and an $\left(\mathrm{FMNH}_{2}\right)$-dependent sulfonate monooxygenase $(s s u D)$, are usually found organized in an operon. In $E$. coli, $P$. aeruginosa, and $P$. putida, the ssu gene cluster also contains $s s u E$, encoding an NADPH-dependent FMN-reducing enzyme that provides $\mathrm{FMNH}_{2}$ to SsuD (Kahnert et al. 2000; van der Ploeg et al. 2001). In addition, E. coli also contains the $\operatorname{tau} A B C D$ genes that are required for the utilization of taurine (aminoethane sulfonate) (van der Ploeg et al. 1997), and $P$. aeruginosa contains an $m s u$ gene cluster that is required for the utilization of methanesulfonate (Kertesz et al. 1999). In contrast to alkane sulfonates, utilization of aromatic sulfonates by $P$. putida requires both the $s s u$ genes as well as the electron transport components AsfA and AsfB (Vermeij and Kertesz 1999). The sulfonates are transported and degraded to sulfite, which then enters central metabolism via the cysteine biosynthetic pathway (Kertesz 1999).

Genes required for assimilation of sulfur from inorganic and organic sources in E. coli and P. putida are regulated by CysB, an LysR-type protein, which is highly conserved among the $\gamma$ and $\beta$ proteobacteria (Iwanika-Nowicka et al. 2007; Kertesz 1999; Kredich 1996; van der Ploeg et al. 2001). In addition, many bacteria require another LysR-type protein, Cbl (for CysB-like), for the utilization of sulfonates (Iwanika-Nowicka and Hryniewicz 1995). The expression of $c b l$ requires CysB, resulting in the expression of sulfonate utilization only in the absence of cysteine and sulfate (Kertesz 1999; van der Ploeg et al. 2001). In contrast, the $\alpha$-proteobacteria to which rhizobia belong does not contain homologues of CysB or Cbl (IwanikaNowicka et al. 2007).

A recent study reported the utilization of taurine as a sulfur source by Sinorhizobium meliloti (Wilson and Kappler 2009). In addition, studies using transcriptomics and proteomics have shown increased expression of putative sulfonate monooxygenases and sulfatases in the soybean nodules induced by Bradyrhizobium japonicum USDA 110 (Delmonte et al. 2010; Mesa et al. 2008; Pessi et al. 2007), and in the nodules of Sesbania rostrata formed by Azorhizobium cualinodans ORS278 (Tsukada et al. 2009). Furthermore, a mutant of $A$. cualinodans ORS578 defective in AZC_3159, a homolog of $E$. coli $s s u E$, formed nodules that were defective in nitrogen fixation (Suzuki et al. 2007). These results suggest that assimi- 
lation of these organosulfur compounds might play an important role not only during symbiosis and nitrogen fixation but also in bacterial survival and competitiveness in soils. Despite these initial studies, however, the details of sulfonate metabolism and its regulation in rhizobia are poorly understood.

In this study, we report on the ability of B. japonicum and $B$. elkanii strains to utilize various inorganic and organic sulfur compounds as sole sulfur sources for growth and identify the role of putative sulfonate monooxygenases in sulfonate utilization. We also show that $B$. japonicum expresses sulfonate monooxygenases and sulfatases in soybean nodules and discuss the potential role of organosulfur utilization in nodulation and nitrogen fixation.

\section{RESULTS AND DISCUSSION}

Putative sulfonate and sulfate-ester utilization genes in the B. japonicum USDA 110 genome.

The $B$. japonicum USDA 110 genome (Kaneko et al. 2002) contains two open reading frames (ORF) annotated as alkanesulfonate monooxygenases (bll6451 and bll7010) that are flanked by genes annotated as subunits of ATP binding cassette $(\mathrm{ABC})$ transporters. The genomic organization of the bll7007-to-bll7011 gene cluster in B. japonicum is similar to the sulfonate utilization gene operons in E. coli (van der Poleg et al. 2001) and P. putida (Kahnert et al. 2000; Vermeij and Kertesz 1999) (Fig. 1). In contrast, the bll6449-to-bll6455 cluster contained two ORF of undefined function (bll6449 and bll6450) and a gene (bll6452) annotated as an acyl-CoA dehydrogenase. BLASTP analysis revealed that it is a DszC monooxygenase family member with $27 \%$ identify and $45 \%$ simi- larity to DszC of $P$. putida KT2440. The DszC is involved in the desulfurization of the heterocyclic $\mathrm{S}$ compound dibenzothiophene. In addition, the genome contains six ORF (bll2665, bl12667, blr3900, bl14738, bl14741, and bll5074) described as putative sulfatases. Further analysis of genome sequences of all legume-nodulating rhizobia using Rhizobase revealed genes annotated as sulfonate transporters, sulfonate monooxygenases, and sulfatases (Supplementary Table S1). The widespread occurrence of organic sulfur utilization genes in rhizobia suggests that organic sulfur compounds might be an important source of $\mathrm{S}$ for rhizobia in soil, as well as during symbioses with legume hosts.

Utilization of organic sulfur by Bradyrhizobium spp. and transcriptional analysis of $B$. japonicum USDA 110 grown on organic and inorganic sulfur sources.

B. japonicum sp. strains USDA 110 and USDA 4 and B. elkanii sp. strain USDA 94 were able to utilize inorganic sulfate and the various sulfonates (butanesulfonate, octane sulfonate, methylmethane sulfonate, 4-[2-hydroxyethyl]-1-piperazineethanesulfonic acid [HEPES], 2-[N-morpholino] ethanesulfonic acid [MES], N-Tris[hydroxymethyl] methyl-2-aminoethanesulfonic acid [TES], CHAPS, 3-morpholinopropanesulfonic acid [MOPS], Ethyl methanesulfonate [EMS], and tarunine), sulfur-ester compound (p-nitrochetachol sulfate), and heterocyclic sulfur compounds (dibenzothiophene) as sole sources of sulfur for growth (Supplementary Table S2).

In order to examine the global control of gene expression by inorganic and organic sulfur sources, whole-genome transcriptional profiles of $B$. japonicum cells grown with cysteine, sulfate, HEPES, and taurine as sole sulfur sources were com-

\section{B. japonicum USDA110}
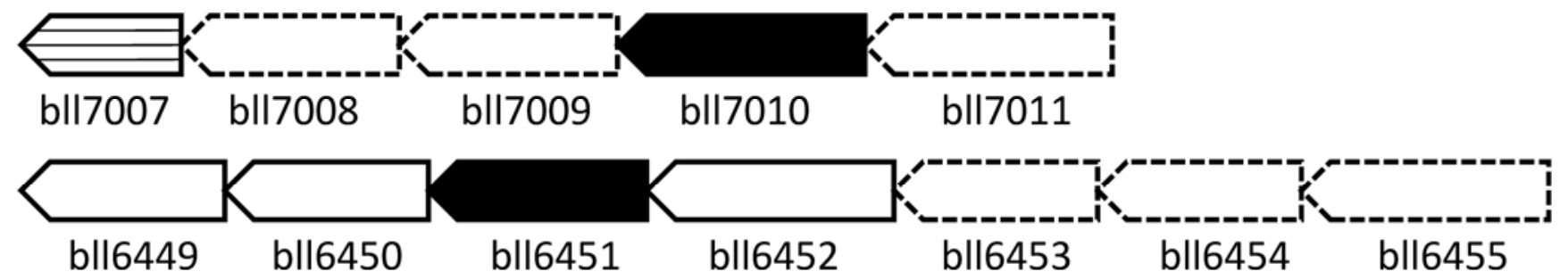

\section{E. coli}

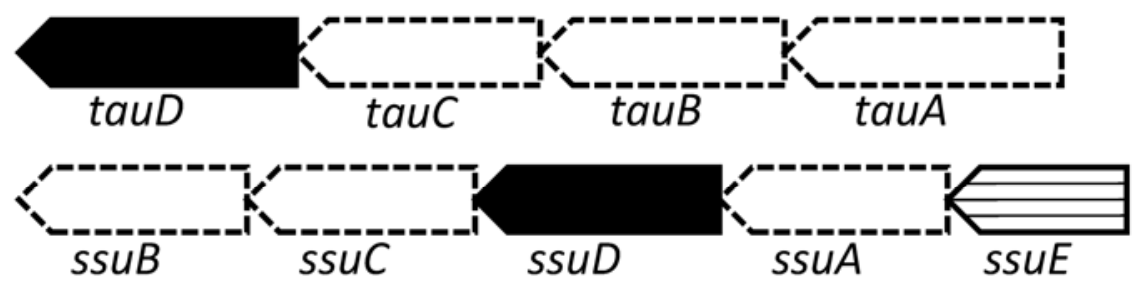

\section{P. putida}

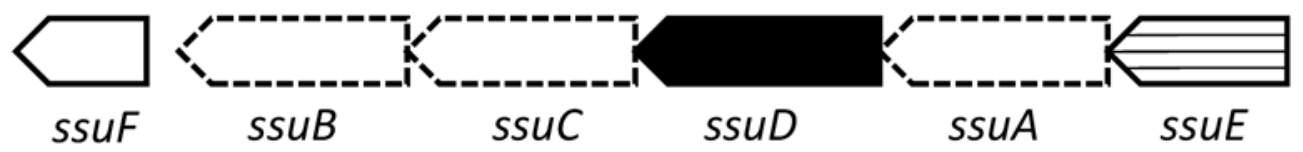

Fig. 1. Genetic organization of sulfonate utilization genes in Bradyrhizobium japonicum USDA 110 and their corresponding genes in Escherichia coli (van der Ploeg et al. 2001) and Pseudomonas putida (Kahnert et al. 2000). Clusters contain gene coding for alkane sulfonate monooxygenase (black bars), FMN reductases (hatched bars), and subunits of ABC transporters (white bars). The bll6449-to-bll6455 cluster lacks the FMN reductase ( $s s u E$ ) gene and contains a gene with similarity to dibenzothiophene-degradative enzyme DszC (bll6452). Note that the putative FMN reductase in B. japonicum is the last gene in the operon whereas it is first gene in E. coli and $P$. putida. 
pared. Three sets of comparisons were made: i) cells grown on cysteine were compared with cells grown on sulfate, HEPES, or taurine; ii) cells grown on sulfate were compared with cells grown on HEPES or taurine; and iii) cells grown on HEPES were compared with those grown on taurine. The complete data generated in the study reported here set is available in the Gene Expression Omnibus database (accession number GSE19039).

The microarray data were analyzed for determining the genes that showed more than twofold induction during growth with sulfate or sulfonates compared with cysteine as $\mathrm{S}$ source (Supplementary Table S3), and of genes that showed induction only during growth with sulfonates compared with growth with sulfate (Supplementary Table S4). In addition, we used $\mathrm{K}$-means clustering to analyze the microarray data as described earlier (Gunasekera et al. 2008; Gyaneshwar et al. 2005). In total, 12, 16, or 20 clusters were generated. Separation of the data into 16 clusters gave the best average expression patterns that were distinct. Because the genes involved in utilization of cysteine, sulfate, and sulfonate utilization were expected to be induced during growth with their respective $\mathrm{S}$ sources, we focused our attention on cluster 5 and cluster 8 containing 165 and 82 genes, respectively (Fig. 2). Genes in cluster 5 showed enhanced expression during growth with cysteine compared with sulfate and sulfonates, and were also highly expressed when cells were grown with taurine compared with sulfate. In contrast, genes in cluster 8 showed enhanced expression during growth with sulfate or sulfonates compared with cysteine.

As expected from the expression pattern, many genes in cluster 8 were annotated as being involved in sulfate and sulfonate metabolism (Table 1; Supplementary Table S5). These included the putative alkane sulfonate monoxygenases and the closely linked ABC transporters (bll6449 to bll6455 and bll7007 to bll7011). This cluster also contained genes putatively involved in uptake and assimilation of sulfate (blr1478

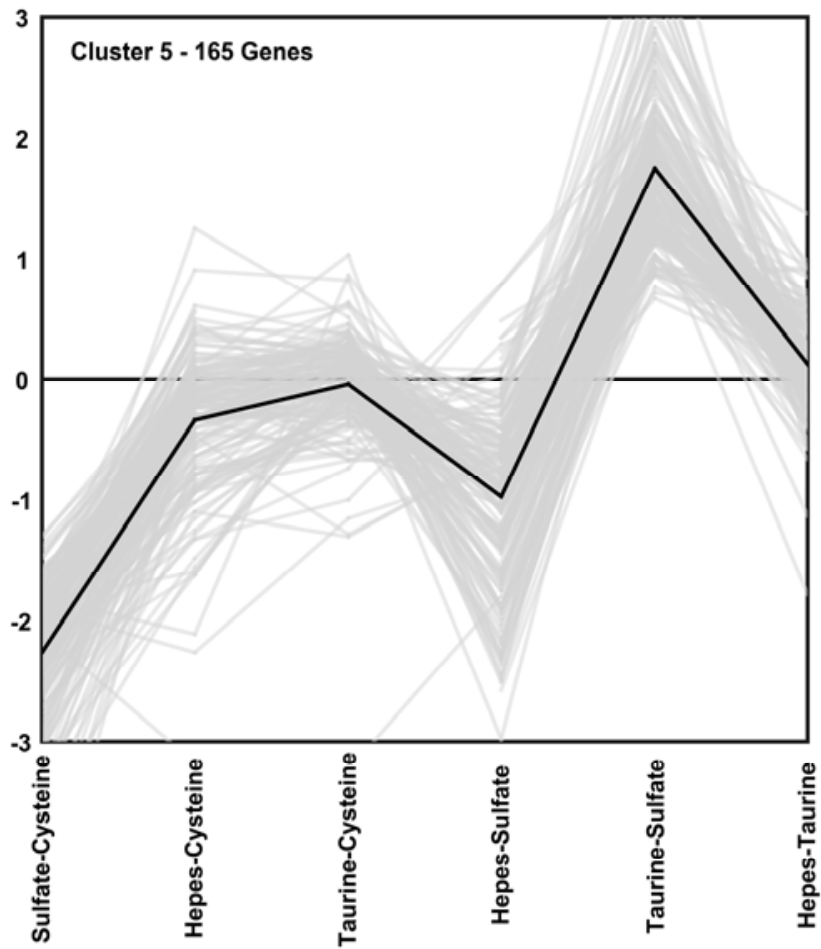

to blr1485), nodQ, and $c y s D$ (Table 1). The expression pattern of these genes suggests that, in B. japonicum USDA 110, cysteine likely represses the expression of genes involved in sulfate and sulfonate metabolism.

An examination of genes in cluster 5 (Supplementary Table S6) revealed an unexpected link between sulfur metabolism and the regulation of nitrogen fixation. Of the 165 genes in cluster 5, $142(85 \%)$ were recently shown to be regulated by the FixLJ-FixK ${ }_{1}-$ FixK $_{2}$ cascade (Mesa et al. 2008). FixK $\mathrm{K}_{2}$ regulates these operons and is part of a regulatory cascade involving FixLJ, a two-component regulatory system that responds to a moderate decrease in oxygen levels (Gilles-Gonsalvez et al. 1991; Gong et al. 1998). However, it was recently shown that Fix $\mathrm{K}_{2}$ is present in the B. japonicum cells grown under aerobic conditions but it is oxidized at one of its cysteine residues (C183). Under microaerobic conditions, C183 gets reduced, thus activating FixK $_{2}$ (Mesa et al. 2009). In contrast to the genes regulated by $\mathrm{FixK}_{2}$ that showed increased expression on cysteine, expression of $\mathrm{FixK}_{2}$ itself was increased during growth with sulfate and sulfonates. Although our results suggests that FixK $_{2}$ can activate its target genes even under aerobic conditions, we favor the view that growth with cysteine could lead to a high intracellular cysteine pool which can help in maintaining FixK $_{2}$ in active configuration by reducing the $\mathrm{C} 183$ residue. This view is further supported by increased expression of FixK $\mathrm{K}_{2}$ in sulfate- and sulfonate-grown cells. Growth on sulfate or sulfonates can result in oxidative stress (Gyaneshwar et al. 2005) leading to the oxidation of $\mathrm{C} 183$ in $\mathrm{FixK}_{2}$, rendering it inactive.

\section{Quantitative reverse-transcription polymerase chain reaction analysis of sulfonate monooxygenase expression in free-living and symbiotic conditions.}

Real-time quantitative reverse-transcription polymerase chain reaction (qRT-PCR) was used to verify the induction of

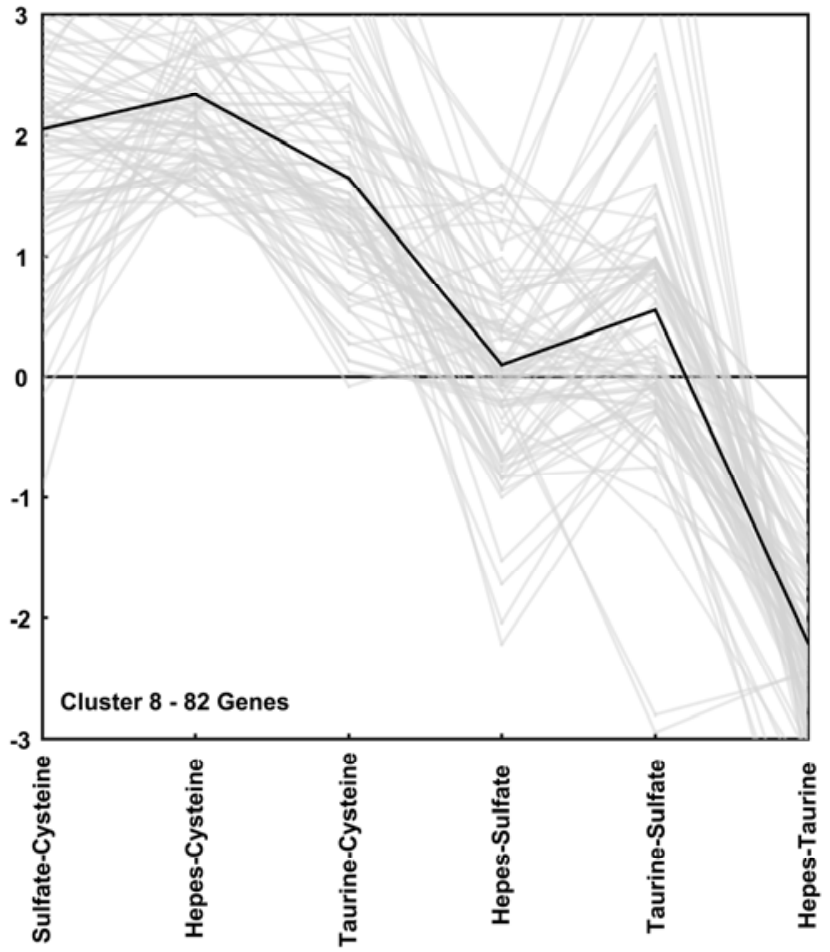

Fig. 2. K-means clustering of the microarray dataset. Each box shows a transcriptional response of genes partitioned into a separate cluster. Cluster number and gene count in the cluster are shown within cluster box. The six pairwise comparisons obtained among different growth conditions are indicated on the $x$ axis. The signal $\log$ ratios of gene expression are indicated on the $y$ axis. The gray lines in each cluster represent the data for individual genes; the black line designates a centroid. 
sulfonate monooxygenases (bl16451 and bll7010) observed in DNA microarray analysis. The expression values was normalized to the mRNA levels of the housekeeping gene parA, which was previously shown to be a good candidate for normalizing gene expression data (Cytryn et al. 2007). Consistent with the microarray analysis, expression levels of bll6451 or bll7010 were the lowest in cells growing with cysteine and were induced approximately three- or 11-fold, respectively, in cells growing with sulfate. Growth with sulfonates led to a further 64- and 343-fold increase in expression of bll6451 and bll7010, respectively (Table 2 ). These results suggest that sulfonate utilization genes in B. japonicum USDA 110 are repressed by cysteine, partially derepressed by sulfate, and fully induced only in the absence of both cysteine and sulfate. Thus, the metabolic regulation of sulfonate utilization gene in $B$. japonicum appears similar to that found in E. coli and $P$. putida (Kertesz 1999; van der Ploeg et al. 2001).

Analysis of the recently reported transcriptomics and proteomics data revealed that both bll6451 and bll7011 were expressed in B. japonicum bacteriods isolated from soybean nodules (Mesa et al. 2008; Pessi et al. 2007). Consistent with these reports, qRT-PCR analysis showed that both bll6451 and bll7010 were significantly expressed in B. japonicum bacteriods in soybean nodules compared with constitutively expressed gene parA. These results suggest that bacteroids are likely utilizing sulfonates or related organic $\mathrm{S}$ compounds for their sulfur nutrition in the root nodules.
Regulation of sulfonate metabolism in B. japonicum.

Previously reported transcriptomic and proteomic analysis suggested that the expression of sulfonate utilization genes might be regulated by the FixLJ-FixK2-FixK1 cascade or through RpoN1+2 (Delmonte et al. 2010; Mesa et al. 2008). However, B. japonicum mutants defective in these genes (Narberhaus et al. 1996; Nellen-Anthamatten et al. 1998) did not show any defect in sulfonate utilization (data not shown), indicating that the genetic regulation of sulfur assimilation in B. japonicum might be through a novel, as-yet-undefined mechanism.

\section{Functional analysis of bll6451 or bll7010 \\ for sulfonate utilization and symbiosis.}

The role of bll6451 or bll7010 in sulfonate utilization was determined by both functional complementation of an $E$. coli mutant defective in sulfonate utilization $(\Delta s s u D \Delta t a u D)$ as well as by generating and analyzing $B$. japonicum mutants with disrupted bll6451 (strain 6451) or bll7010 (strain 7010). The plasmid bll7010 could complement the E. coli ( $\Delta s s u D$ $\triangle t a u D$ ) mutant for growth on HEPES but not on taurine. In contrast, bll6451 failed to complement the mutant growth with HEPES or taurine (data not shown). Consistent with these observations, B. japonicum sp. strain 7010 failed to grow with HEPES but grew similarly to the wild type on taurine, whereas strain 6451 could grow well with both HEPES or taurine but could not utilize dibenzothiophene (Table 3). These results

Table 1. Genes of sulfate or sulfonate metabolism part of cluster 8 and their induction ratios in various $\mathrm{S}$ sources

\begin{tabular}{|c|c|c|c|c|c|}
\hline \multirow[b]{2}{*}{ Gene no. } & \multirow[b]{2}{*}{ Gene name $^{b}$} & \multirow[b]{2}{*}{ Gene description } & \multicolumn{3}{|c|}{$\log _{2} R / G$ ratios ${ }^{a}$} \\
\hline & & & Sulfate & HEPES & Taurine \\
\hline blr1233 & $\ldots$ & Putative sulfonate-binding protein & 1.5 & 2.5 & 1.0 \\
\hline bll1475 & $\operatorname{nod} Q$ & NodQ bifunctiol enzyme & 4.5 & 3.2 & 4.3 \\
\hline bl11476 & $\operatorname{cys} \tilde{D}$ & Sulfate adenylate transferase & 4.1 & 3.6 & 3.1 \\
\hline blr1479 & cysI* & Sulfite reductase* & 3.6 & 3.1 & 1.8 \\
\hline blr1481 & cys $H$ & Phosphoadenosine phosphosulfate reductase & 3.2 & 2.6 & 2.1 \\
\hline blr1482 & $\operatorname{cys} P^{*}$ & $\mathrm{ABC}$ transporter sulfate-binding protein & 2.9 & 3.4 & 2.3 \\
\hline blr1483 & $\operatorname{cys} T^{*}$ & Sulfate $\mathrm{ABC}$ transporter permease protein & 1.8 & 2.0 & 2.2 \\
\hline blr1485 & $\operatorname{cys} A^{*}$ & Sulfate ABC transporter ATP-binding protein & 1.9 & 1.9 & 1.5 \\
\hline bl16449 & $\ldots$ & Hypothetical protein bll6449 & 4.5 & 5.2 & 4.6 \\
\hline bll6450 & $\ldots$ & Probable substrate-binding protein & -0.2 & 1.9 & 1.7 \\
\hline bll6451 & $\ldots$ & Probable alkanesulfonate monooxygenase & 0.6 & 2.8 & 3.4 \\
\hline bll6453 & $\ldots$ & ABC transporter ATP-binding protein & 0.7 & 1.8 & 1.2 \\
\hline bll6455 & $\ldots$ & $\mathrm{ABC}$ transporter substrate-binding protein & 0.5 & 2.9 & 0.9 \\
\hline b117007 & $s s u E^{*}$ & Putative oxidoreductase & 0.3 & 2.2 & 1.4 \\
\hline bll7008 & $\operatorname{ssu} C^{*}$ & Aliphatic sulfonate $\mathrm{ABC}$ transporter & 0.8 & 3.0 & 2.6 \\
\hline bll7009 & $\operatorname{ssu} B^{*}$ & Aliphatic sulfonate transporter permease protein & 2.1 & 2.7 & 1.4 \\
\hline bll7010 & $s s u D$ & Sulfonate monooxygese & 2.7 & 4.1 & 2.2 \\
\hline bll7011 & $\operatorname{ssu} A^{*}$ & Aliphatic sulfonate-binding protein & 2.6 & 4.7 & 2.0 \\
\hline
\end{tabular}

${ }^{a}$ Ratios compared with growth on cysteine. HEPES = 4-(2-hydroxyethyl)-1-piperazineethanesulfonic acid.

${ }^{\mathrm{b}}$ An asterisk (*) indicates suggested gene name and description based on this study.

Table 2. Quantitative reverse-transcription polymerase chain reaction analysis of sulfonate oxygenase genes in Bradyrhizobium japonicum USDA 110 cells

\begin{tabular}{|c|c|c|c|c|c|c|}
\hline \multirow[b]{4}{*}{ S source or condition } & \multicolumn{6}{|c|}{ Gene } \\
\hline & \multicolumn{3}{|c|}{ bll6451 } & \multicolumn{3}{|c|}{ bll7010 } \\
\hline & \multirow[b]{2}{*}{ Expression $^{\text {a }}$} & \multicolumn{2}{|c|}{ Expression ratio } & \multirow[b]{2}{*}{ Expression $^{a}$} & \multicolumn{2}{|c|}{ Expression ratio } \\
\hline & & $\mathrm{Na}_{2} \mathrm{SO}_{4}$ & Cysteine & & $\mathrm{Na}_{2} \mathrm{SO}_{4}$ & Cysteine \\
\hline \multicolumn{7}{|l|}{ Culture } \\
\hline $\mathrm{Na}_{2} \mathrm{SO}_{4}$ & $0.31 \pm 0.22$ & 1.0 & 2.8 & $0.52 \pm 0.35$ & 1.0 & 11.4 \\
\hline HEPES $^{\mathrm{b}}$ & $1.88 \pm 0.93$ & 6.1 & 17.1 & $9.74 \pm 1.42$ & 18.9 & 214.5 \\
\hline Taurine & $7.05 \pm 2.62$ & 23.0 & 63.9 & $15.6 \pm 2.78$ & 30.3 & 343.7 \\
\hline Cysteine & $0.11 \pm 0.01$ & 0.4 & 1.0 & $0.045 \pm 0.006$ & 0.1 & 1.0 \\
\hline \multicolumn{7}{|l|}{ In planta } \\
\hline Bacteroid & $0.80 \pm 0.10$ & 2.6 & 7.3 & $0.53 \pm 0.16$ & 1.0 & 11.8 \\
\hline
\end{tabular}

a Absolute expression values were normalized to the housekeeping gene parA. Values are means \pm standard deviation of three biological replicates.

${ }^{\mathrm{b}}$ HEPES = 4-(2-hydroxyethyl)-1-piperazineethanesulfonic acid. 
suggest that, in B. japonicum, the bll7007-to-bll7011 operon is mainly involved in the utilization of alkane sulfonates and the bll6449-to-bll6454 operon may be important for utilization of heterocyclic sulfur compounds. The utilization of taurine, however, is independent of these two sulfonate utilization clusters. However, both these mutants were not significantly affected in their symbiotic interaction with soybean and formed nodules that were similar to the wild type strain (data not shown). The lack of effect on the nodulation could reflect the functional redundancy of the sulfonate utilization system in B. japonicum or availability of other $\mathrm{S}$ sources such as sulfate-esters (discussed below) or inorganic $\mathrm{S}$.

\section{Sulfatase activity of $B$. japonicum USDA 110 in symbiosis.}

Apart from sulfonates, sulfate-esters are major organic sulfur compounds found in soils. In addition, plants contain sulfateester compounds such as choline-sulfate in high amounts (Nissen and Benson 1961). B. japonicum USDA 110 contains six ORF annotated as sulfatases, indicating that such compounds could be important for its $S$ nutrition in soil as well as during symbiosis. The sulfatase activity of B. japonicum USDA 110 in free-living or symbiotic conditions was determined using chromogenic substrate 5-bromo-4-chloro-3-indoxyl sulfate (X-sulfate). B. japonicum cells growing on arabinose-gluconate $(\mathrm{AG})$ medium showed intense blue color after 3 days of incubation (not shown) and the soybean nodules containing B. japonicum bacteroids cleaved X-sulfate and were stained blue (Fig. 3). No color was observed when soybean roots were incubated with $\mathrm{X}$-sulfate. This indicates that the detected sulfatase activity was due to the bacteria present in the nodules and not from the soybean plant. These results are in contrast to an earlier study that did not detect B. japonicum sulfatase activity in soybean nodules (O'Hara et al. 1987) but are in agreement with recent transcriptomic and proteomic studies showing expression of an arylsulfatase encoded by bll2665 (Delmonte et al. 2010; Mesa et al. 2009). These results suggest that $\mathrm{S}$-ester compounds might be utilized by $B$. japonicum for its sulfur nutrition in the plant host.

In summary, Bradyrhizobium spp. strains are metabolically diverse and have the ability to utilize a wide variety of sulfur compounds, including alkane sulfonates and sulfate-esters, to support growth and metabolism. Genomic, transcriptomic, and genetic analyses indicates that $B$. japonicum USDA 110 can utilize sulfonate and heterocyclic sulfur compounds via two operons, bll7007 to bll7011 and bll6449 to bll6455. Additionally, B. japonicum USDA 110 also expresses the sulfonate monooxygenases and sulfatases in nodules formed on soybean. The expression of genes involved in organic sulfur utilization in root nodules suggests that $B$. japonicum USDA 110 in the bacteroid state may obtain sulfur from sulfonates or sulfurester compounds. Interestingly, genes comprising the sulfonate monooxygenases operons were recently shown to be involved in host-specific adaptation of B. japonicum USDA 110 (Koch et al. 2010). It is possible that B. japonicum undergoes different levels of sulfur starvation or encounters different sources of sulfonates in various legume hosts. Because sulfur-esters and sulfonates may constitute up to $95 \%$ of total sulfur in aero-

Table 3. Growth (optical density at $600 \mathrm{~nm}$ ) of Bradyrhizobium japonicum and putative sulfonate monooxygenase mutants with different organic sulfur sources

\begin{tabular}{lccc}
\hline & \multicolumn{3}{c}{ Sulfur sources } \\
\cline { 2 - 4 } Strain & HEPES & Dibenzothiophene & Taurine \\
\hline USDA 110 & $0.52 \pm 0.04$ & $0.45 \pm 0.05$ & $0.72 \pm 0.03$ \\
7010 & $0.05 \pm 0.01$ & $0.52 \pm 0.04$ & $0.62 \pm 0.05$ \\
6451 & $0.49 \pm 0.06$ & $0.04 \pm 0.01$ & $0.59 \pm 0.07$ \\
\hline
\end{tabular}

bic soils, our results suggest that these sulfur sources likely play an important role in the soil survival strategy of Bradyrhizobium spp. and in their symbiotic association with their cognate legume host.

\section{MATERIALS AND METHODS}

Bacterial strains, media, and growth conditions.

Bradyrhizobium cells were grown at $30^{\circ} \mathrm{C}$, with shaking at $200 \mathrm{rpm}$, in AG medium (Sadowsky et al. 1987), or in sulfurfree minimal medium (MHM) containing $3.3 \mathrm{~g}$ of $\mathrm{NaH}_{2} \mathrm{PO}_{4}$. $\mathrm{H}_{2} \mathrm{O}, 3.8 \mathrm{~g}$ of $\mathrm{Na}_{2} \mathrm{HPO}_{4}, 6.7 \mathrm{mg}$ of $\mathrm{FeCl}_{3} \cdot 6 \mathrm{H}_{2} \mathrm{O}, 0.15 \mathrm{~g}$ of $\mathrm{MgCl}_{2} \cdot 6 \mathrm{H}_{2} \mathrm{O}, 13 \mathrm{mg}$ of $\mathrm{CaCl}_{2} \cdot 2 \mathrm{H}_{2} \mathrm{O}, 0.202 \mathrm{~g}$ of $\mathrm{NaCl}, 0.32$ $\mathrm{g}$ of $\mathrm{NH}_{4} \mathrm{Cl}, 1 \mathrm{~g}$ of L-arabinose, and $1 \mathrm{~g}$ of sodium gluconate, pH 7.0, per liter. The E. coli strains were grown on Luria-Bertani medium. Ampicillin and kanamycin $(100 \mu \mathrm{g} / \mathrm{ml})$ were added as required.

\section{Utilization of sulfur sources by Bradyrhizobium strains.}

Bradyrhizobium strains were grown in $100 \mathrm{ml}$ of AG medium at $30^{\circ} \mathrm{C}$ until stationary phase. Cells were collected by centrifugation at $10,000 \times g$ for $10 \mathrm{~min}$, washed twice in sulfur-free MHM, resuspended in $100 \mathrm{ml}$ of the same medium, and incubated at $30^{\circ} \mathrm{C}$ for 4 days to induce sulfur starvation. Aliquots of the cell suspensions $(25 \mu \mathrm{l})$ were individually inoculated into $5 \mathrm{ml}$ of MHM supplemented with $2 \mathrm{mM} \mathrm{Na}_{2} \mathrm{SO}_{4}$ or different sulfur sources, including the sulfonate organic buffers HEPES, MES, MOPS, N-cyclohexyl-2-aminoethanesulfonic acid, 3-(cyclohexylamino)-1-propanesulfonic acid, and TES. EMS, butane sulfonate, octanesulfonate, a substituted sulfonate (taurine), and the aromatic sulfonates 2-anthraquinone sulfonate and 4,5, dihydroxy-2-7-napthalene sulfonate were also tested as $\mathrm{S}$ sources for the bradyrhizobia. Cultures were incubated at $30^{\circ} \mathrm{C}$, with shaking, and the optical density at $600 \mathrm{~nm}\left(\mathrm{OD}_{600}\right)$ was measured after 7 days of growth.

\section{Sample preparation for microarray analyses.}

Sulfur-starved B. japonicum USDA 110 cells were inoculated into $15 \mathrm{ml}$ of MHM medium individually supplemented with 2 $\mathrm{mM}$ each cysteine, sodium sulfate, HEPES, or taurine to an initial $\mathrm{OD}_{600}=0.02$. Two biological replicates were used for each analysis. Cultures were incubated at $30^{\circ} \mathrm{C}$ until $\mathrm{OD}_{600}$ reached approximately 0.5 to 0.6 , and $1.5 \mathrm{ml}$ of cold stop solution (5\% water-saturated phenol in $95 \%$ ethanol) was added to

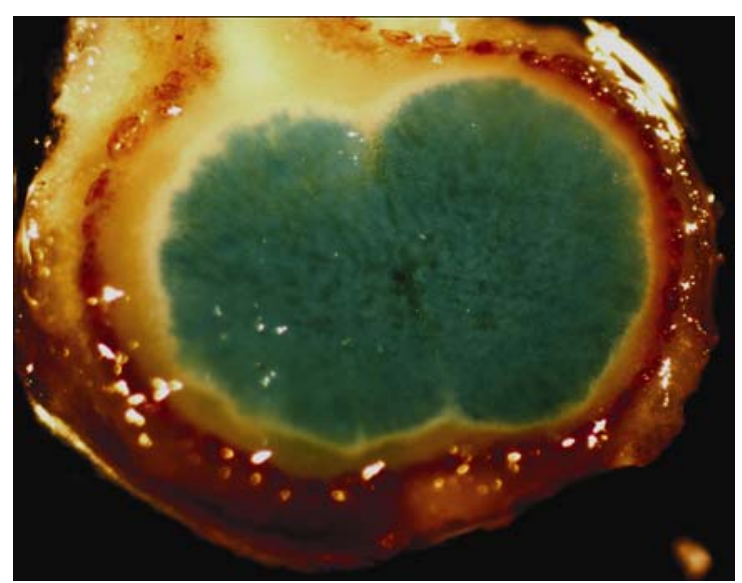

Fig. 3. Sulfatase activity of Bradyrhizobium japonicum USDA 110 bacteroids in soybean nodules. Nodules were collected and incubated in 100 $\mathrm{mM}$ potassium phosphate buffer, $\mathrm{pH}$ 7.0, containing 5-bromo-4-chloro-3indoxyl sulfate (X-sulfate). Highly stained bacteroids can be seen in the nodule. No color was detected in plant roots incubated with X-sulfate (not shown). 
each culture. The cultures were centrifuged at $10,000 \times g$ for $10 \mathrm{~min}$ at $4^{\circ} \mathrm{C}$, the collected cells were immediately frozen by immersion in liquid nitrogen, and cell pellets were stored at $80^{\circ} \mathrm{C}$ until used for RNA extraction. Total RNA was extracted using the hot phenol method (Bittner et al. 2003), digested with DNaseI, and purified as described previously (Chang et al. 2007). RNA quality was determined by electrophoresis on $0.8 \%$ agarose gels.

\section{Microarray expression analysis.}

Transcriptional profiling of B. japonicum USDA 110 was performed using whole-genome 70-mer oligonucleotide arrays that contain probes for 8,453 ORF printed on glass slides (Chang et al. 2007). These arrays were previously used for characterizing responses of B. japonicum to chemoautotrophic growth (Franck et al. 2008) or to desiccation stress (Cytryn et al. 2007). The cDNA synthesis, fluorescent dye labeling, microarray hybridization, and image acquisition procedures used were essentially as previously published (Chang et al. 2007; Cytryn et al. 2007). Spot intensities were obtained from each slide using GenePix Pro 6.0 software (Molecular Devices Corp., Sunnyvale, CA, U.S.A.). All GenePix results and data files produced by the scanning software were uploaded into CARMAweb (Rainer et al. 2006) for normalization and data analysis. Median F635 and B635 values were used for each spot, and flagged spots were ignored. The algorithms used were NORMEXP (correction of background signal), LOESS (within-array normalization), and AQUANTILE for (betweenarray standardization) (Smyth and Speed 2003). For each comparison of culture growth in two different media, two replicate arrays were produced with swap-dye patterns; these were averaged as biological replicates (arithmetic mean). To generate lists of differentially expressed genes for each comparison, the genes with $|\mathrm{M}| \geq 1$ and $|\mathrm{A}| \geq 10 \%$ percentile range in that comparison were considered $\left[\left(\mathrm{M}=\log _{2}(\mathrm{R} / \mathrm{G}) ; \mathrm{A}=\log _{2}(\mathrm{R} \times \mathrm{G})\right]\right.$. The unions and intersections of the gene lists among comparisons were visualized as Venn diagrams.

\section{Data clustering.}

The normalized data set was imported into GENESIS microarray analysis software (version 1.7) (Sturn et al. 2002) as described (Gyaneshwar et al. 2005). Euclidean distance was used as a measure of gene profile similarity. $\mathrm{K}$-means clustering $(\mathrm{K}=$ 16) and principal components analysis were done to analyze the microarray data, essentially as described earlier (Gunasekera et al. 2008). Gene expression changes were determined for the following comparisons: growth in cysteine (Cys) versus sulfate; Cys versus HEPES; Cys versus taurine; sulfate versus HEPES, sulfate versus taurine, and HEPES versus taurine.

\section{Construction of bll7010 and bll6451 mutants of $B$. japonicum.}

Genes bll7010 and bll6451 were amplified by PCR using primers targeting the upstream and downstream sequences of these genes (Supplementary Table S7). PCR products were ligated into pBlueScript $\mathrm{SK}(+)$ vector and a kanamycin resistance cassette was inserted into each fragment. The disrupted genes were PCR amplified, cloned into suicide vector pSUP202, and transferred into B. japonicum USDA 110 by conjugation, and transconjugants were selected for kanamycin resistance. The correct genomic structure of the disrupted genes containing the kanamycin-resistance cassette was verified by PCR. The resulting mutants were named 6451 and 7010.

\section{Soybean planting and bacteroid isolation from nodules.}

Wild-type $B$. japonicum USDA 110 was grown in AG medium and diluted to $10^{7}$ cells $/ \mathrm{ml}$ in sterile water, and $1-\mathrm{ml}$ ali- quots of the dilutions were inoculated onto surface-sterilized Glycine max 'Lambert' seed. Plant assays were done in sterile Leonard jar assemblies containing a 3:1 mixture of vermiculite and perlite as previously described (Sadowsky et al. 1987). Soybean seed were surface sterilized by immersion in $100 \%$ ethanol for $5 \mathrm{~s}$, followed by treatment with $1.0 \%$ sodium hypochlorite for $5 \mathrm{~min}$. Seed were washed 10 times with sterile distilled water prior to planting. After inoculation, seed were covered with a 1-cm layer of sterilized paraffin-coated sand. Plants were watered with nitrogen-free plant nutrient solution (Keyser and Cregan 1987), and incubated for 30 days in a plant growth chamber at $25^{\circ} \mathrm{C}$, with a photoperiod of $16 \mathrm{~h}$.

To isolate bacteroids from soybean nodules, approximately $1 \mathrm{~g}$ of fresh nodules was sampled from 4-week-old soybean plants. The nodules were immediately ground in liquid nitrogen, and the resulting powders were suspended with $1.5 \mathrm{ml}$ of cold phosphate-buffered saline buffer. The homogenate was filtered through three layers of Miracloth (Calbiochem Inc., La Jolla, CA, U.S.A.), and centrifuged at $200 \times g$ for $5 \mathrm{~min}$ to remove debris. The pellet was discarded, and the supernatant was transferred to a clean centrifuge tube and centrifuged at $8,000 \times g$ for $10 \mathrm{~min}$ to pellet the bacteroids. RNA was isolated from the bacteroids by using the hot-phenol method (Bittner et al. 2003).

\section{Real-time qRT-PCR.}

cDNA for qRT-PCR was synthesized from $1 \mu \mathrm{g}$ of total RNA template, either from cells grown with different sulfur sources or from bacteriods isolated from nodules. A 1- $\mu$ l aliquot of random hexamers at $250 \mathrm{ng} / \mu \mathrm{l}$ (Invitrogen Co., Carlsbad, CA, U.S.A.) and $1 \mu \mathrm{l}$ of $10 \mathrm{mM}$ dNTP mix were added to $11 \mu \mathrm{l}$ of RNA solution. The mixture was heated at $65^{\circ} \mathrm{C}$ for $5 \mathrm{~min}$, chilled on ice for $1 \mathrm{~min}$, and $4 \mu \mathrm{l}$ of $5 \times$ firststrand buffer, $1 \mu \mathrm{l}$ of $0.1 \mathrm{M}$ dithiothreitol, $1 \mu \mathrm{l}$ of RNaseOUT (Invitrogen), and 200 units of Superscript III reverse transcriptase (Invitrogen Co.) were added to the solution. The solution was incubated at $50^{\circ} \mathrm{C}$ for $1 \mathrm{~h}$, then incubated at $70^{\circ} \mathrm{C}$ for $15 \mathrm{~min}$. The resultant sample was kept at $-20^{\circ} \mathrm{C}$ as cDNA samples until qRT-PCR was performed. Reaction mixtures $(25 \mu \mathrm{l})$ contained cDNA synthesized from $50 \mathrm{ng}$ of RNA, $12.5 \mu$ of iTaq SYBR Green Supermix with ROX (Bio-Rad, Hercules, CA, U.S.A.), $11.25 \mu$ of nuclease-free water, and $0.5-\mu \mathrm{M}$ concentrations each of forward and reverse gene-specific primers. The primer sets used in these PCR tests were as follows: bll6451-F2 and bll6451-R2 (for bll6451), bll7010-F2 and bll7010-R2 (for bll7010), and bll0631-F and bll0631-R (for parA). The qRT-PCRs were run on an Applied Biosystems (Foster City, CA, U.S.A.) 7500 real-time PCR system using Sequence Detection System software, version 1.3. The PCR program consisted of an initial denaturation of $95^{\circ} \mathrm{C}$ for $2 \mathrm{~min}$, followed by 40 cycles of denaturation at $95^{\circ} \mathrm{C}$ for $15 \mathrm{~s}$, and annealing and extension at $60^{\circ} \mathrm{C}$ for $1 \mathrm{~min}$. Expression values for three biological replicates for each treatment were normalized to the expression level of parA (bll0631), which is a housekeeping gene in the B. japonicum USDA 110 genome (Cytryn et al. 2007).

\section{Histochemical staining for sulfatase expression.}

At least three nodules from three different soybean plants were assessed for the expression of sulfatase, using the chromogenic substrate X-sulfate. The nodules were bisected using a sterile razor blade and incubated in $0.1 \mathrm{M}$ phosphate buffer, $\mathrm{pH} 7.0$, containing X-sulfate at $50 \mu \mathrm{g} \mathrm{ml}^{-1}$ and $0.01 \%$ Triton$\mathrm{X}-100$. To avoid the induction of sulfatases during the incubation, chloramphenicol was added to the assay at $100 \mu \mathrm{g} \mathrm{ml}^{-1}$. The activity of sulfatases was monitored by development of blue color, indicating hydrolysis of X-sulfate. 


\section{ACKNOWLEDGMENTS}

This work was supported, in part, by a grant from the College of Letters and Sciences and Research Growth Initiative, University of Wisconsin, Milwaukee (to P. Gyaneshwar) and by the Minnesota Agricultural Experiment Station (to M. J. Sadowsky). We thank H.-M. Fisher and F. Narberhaus for B. japonicum mutants and D. Saffarini and M. McBride for critical reading of the manuscript.

\section{LITERATURE CITED}

Autry, A. R., and Fitzgerald J. W. 1990. Sulfonate S: A major form of forest soil organic sulfur. Biol. Fertil. Soils 10:50-56.

Bittner, M., Butow, R., DeRisi, J., Diehn, M., Eberwine, J., Epstein, C. B., Glynne, R., Grimmond, S., Ideker, T., Kacharmina, J. E., Katsabanis, S., Khan, J., Lee, J., Liu, C. L., Marciano, P., Marincola, F. M., McIntosh, T., Monte, D., Pollack, J. R., Rhodius, V., Somerville, S., Tom, E., Wang, E., Wei, J. S., Willhite, D., and Ybarra, S. 2003. Expression analysis of RNA. Pages 101-288 in: DNA Microarrays: A Molecular Cloning Manual. D. Bowtell and J. Sambrook, eds. Cold Spring Harbor Laboratory Press, Cold Spring Harbor, NY, U.S.A.

Chang, W., Franck, W., Cytryn, E., Jeong, S., Joshi, T., Emerich, D., Sadowsky, M., Xu, D., and Stacey, G. 2007. An oligonucleotide microarray resource for transcriptional profiling of Bradyrhizobium japonicum. Mol. Plant-Microbe Interact. 20:1298-1307.

Cytryn, E., Sangurdekar, D., Streeter, J., Franck, W., Chang, W., Stacey, G., Emerich, D., Joshi, T., Xu, D., and M. Sadowsky. 2007. Transcriptional and physiological responses of Bradyrhizobium japonicum to desiccation-induced stress. J. Bacteriol. 189:6751-6762.

Delmotte, N., Ahrens, C. H., Knief, C., Qeli, E., Koch, M., Fischer, H. M., Vorholt, J. A., Hennecke, H., and Pessi, G. 2010. An integrated proteomics and transcriptomics reference data set provides new insights into the Bradyrhizobium japonicum bacteroid metabolism in soybean root nodules. Proteomics 10:1391-400.

Franck, W. L., Chang, W.-S., Qiu, J., Sugawara, M., Sadowsky, M. J., Smith, S. A., and Stacey, G. 2008. Whole-genome transcriptional profiling of Bradyrhizobium japonicum during chemoautotrophic growth. J. Bacteriol. 190:6697-6705.

Gilles-Gonzalez, M. A., Ditta, G. S., and Helinski, D. R. 1991. A haemoprotein with kinase activity encoded by the oxygen sensor of Rhizobium meliloti. Nature 350:170-172.

Gong, W., Hao, B., Mansy, S. S., Gonzalez, G. M., Gilles-Gonzalez, A., and Chan, M. K. 1998. Structure of a biological oxygen sensor: A new mechanism for heme-driven signal transduction. Proc. Natl. Acad. Sci. U.S.A. 95:15177-15182.

Gunasekera, T., Csonka, L., and Paliy, O. 2008. Genome-wide transcriptional responses of Escherichia coli $\mathrm{K}-12$ to continuous osmotic and heat stresses. J. Bacteriol. 190:3712-3720.

Gyaneshwar, P., Paliy, O., McAuliffe, J., Popham, D., Jordan, M., and Kustu, S. 2005. Sulfur and nitrogen limitation in Escherichia coli K-12: Specific homeostatic responses. J. Bacteriol. 187:1074-1090.

Iwanicka-Nowicka, R., and Hryniewicz, M. 1995. A new gene, $c b l$, encoding a member of the LysR family of transcriptional regulators belongs to Escherichia coli cys regulon. Gene 166:11-17.

Iwanicka-Nowicka, R., Zielak, A., Cook, A. M., Thomas, M. S., and Hryniewicz, M. M. 2007. Regulation of sulfur assimilation pathways in Burkholderia cenocepacia: Identification of transcription factors CysB and SsuR and their role in control of target genes. J. Bacteriol. 189:1675-1688.

Kahnert A., Vermeij, P., Wietek, C., James, P., Leisinger, T., and Kertesz, M. A. 2000. The ssu locus plays a key role in organosulfur metabolism in Pseudomonas putida S-313. J. Bacteriol. 182:2869-2878.

Kaneko, T., Nakamura, Y., Sato S., Minamisawa, K., Uchiumi, T., Sasamoto, S., Watanabe, A., Idesawa, K., Iriguchi, M., Kawashima, K., Kohara, M., Matsumoto, M., Shimpo, S., Tsuruoka, H., Wada, T., Yamada, M., and Tabata, S. 2002.Complete genomic sequence of nitrogen-fixing symbiotic bacterium Bradyrhizobium japonicum USDA 110. DNA Res. 9:189-197.

Kertesz, M. 1999. Riding the sulfur cycle-metabolism of sulfonates and sulfate esters in gram-negative bacteria. FEMS (Fed. Eur. Microbiol. Soc.) Microbiol. Rev. 24:135-175.

Kertesz M. A., Schmidt-Larbig, K., and Wüest, T. 1999. A novel reduced flavin mononucleotide-dependent methanesulfonate sulfonatase encoded by the sulfur-regulated $m s u$ operon of Pseudomonas aeruginosa. J. Bacteriol. 181:1464-1473.

Keyser, H. H., and Cregan, P. B. 1987. Nodulation and competition for nodulation of selected genotypes among Bradyrhizobium japonicum serogroup 123 isolates. Appl. Environ. Microbiol. 53:2631-2635.

Koch, D. J., Rückert, C., Rey, D. A., Mix, A., Pühler, A., and Kalinowski,
J. 2005. Role of the ssu and seu genes of Corynebacterium glutamicum ATCC 13032 in utilization of sulfonates and sulfonate esters as sulfur sources. Appl. Environ. Microbiol. 71:6104-6114.

Koch, M., Delmotte, N., Rehrauer, H., Vorholt, J. A., Pessi, G., and Hennecke, H. 2010. Rhizobial adaptation to hosts, a new facet in the legume root nodule symbiosis. Mol. Plant-Microbe Interact. 23:784-90.

Kredich, N. M. 1996. Biosynthesis of cysteine. Pages 514-527 in: Escherichia coli and Salmonella: Cellular and Molecular Biology, 2nd ed. Vol. 1. F. C. Neidhardt, R. Curtiss, III, J. L. Ingraham, E. C. C. Lin, K. B. Low, B. Magasanik, W. S. Reznikoff, M. Riley, M. Schaechter, and H. H. Umbarger, eds. ASM Press, Washington, DC.

Mesa, S., Hauser, F., Friberg, M., Malaguti, E., Fischer, H., and Hennecke, H. 2008. Comprehensive assessment of the regulons controlled by the FixLJ-FixK2-FixK1 cascade in Bradyrhizobium japonicum. J. Bacteriol. 190:6568-6579.

Mesa, S., Reutimann, L., Fischer, H.-M., and Hennecke, H. 2009. Posttranslational control of transcription factor FixK2, a key regulator for the Bradyrhizobium japonicum-soybean symbiosis. Proc. Natl. Acad. Sci. U.S.A. 106:21860-21865.

Mirleau, P., Wogelius, R., Smith, A., and Kertesz, M. A. 2005. Importance of organosulfur utilization for survival of Pseudomonas putida in soil and rhizosphere. Appl. Environ. Microbiol. 71:6571-6577.

Narberhaus, F., Weiglhofer, W., Fischer, H. M., and Hennecke, H. 1996. The Bradyrhizobium japonicum rpoHl gene encoding a sigma32 like protein is part of a unique heat shock gene cluster together with growESL1 and three small heat shock genes. J. Bacteriol. 178:5337-5346.

Nellen-Anthamatten, D., Rossi, P., Preisig, O., Kullik, L., Babst, M., Fischer, H. M., and Hennecke, H. 1998. Bradyrhizobium japonicum FixK2, a crucial distributor in the FixLJ-dependent regulatory cascade for control of genes inducible by low oxygen levels. J. Bacteriol. 180:5251-5255.

Nissen, P., and Benson, A. A. 1961. Choline sulfate in higher plants. Science 134:1759.

O'Hara G. W., Franklin, M., and Dilworth M. J. 1987. Effect of sulfur supply on sulfate uptake, and alkaline sulfatase activity in free-living and symbiotic bradyrhizobia. Arch. Microbiol. 149:163-167.

Pessi, G., Ahrens, C. H., Rehrauer, H., Lindemann, A., Hauser, F., Fischer, H. M., and Hennecke, H. 2007. Genome-wide transcript analysis of Bradyrhizobium japonicum bacteroids in soybean root nodules. Mol. Plant-Microbe Interact. 20:1353-1363.

Rainer, J., Sanchez-Cabo, F., Stocker, G., Sturn, A., and Trajanosk, Z. 2006. CARMAweb: Comprehensive R- and bioconductor-based web service for microarray data analysis. Nucleic Acids Res. 34:W498503.

Sadowsky, M. J., Tully, R. E., Cregan, P. B., and Keyser, H. H. 1987. Genetic diversity in Bradyrhizobium japonicum serogroup 123 and its relation to genotype nodulation of soybean. Appl. Environ. Microbiol. 53:1785-1789.

Smyth, G. K., and Speed, T. 2003. Normalization of cDNA microarray data. Methods 3:265-273.

Sturn, A., Quackenbush, J., and Trajanoski, Z. 2002. Genesis: Cluster analysis of microarray data. Bioinformatics 18:207-208.

Suzuki, S., Aono, T., Lee, K. B., Suzuki, T., Liu, C. T., Miwa, H., Wakao, S., Iki, T., and Oyaizu, H. 2007. Rhizobial factors required for stem nodule maturation and maintenance in Sesbania rostrata-Azorhizobium caulinodans ORS571 symbiosis. Appl. Environ. Microbiol. 73:66506659.

Tsukada, S., Aono, T., Akiba, N., Lee, K. B., Liu, C. T., Toyazaki, H., and Oyaizu, H. 2009. Comparative genome-wide transcriptional profiling of Azorhizobium cualinodans ORS571 grown under free-living and symbiotic conditions. Appl. Environ. Microbiol. 75:5037-5046.

van der Ploeg, J. R., Iwanicka-Nowicka, R., Kertesz, M. A., Leisinger, T., and Hryniewicz, M. M. 1997. Involvement of CysB and Cbl regulatory proteins in expression of the tauABCD operon and other sulfate starvation-inducible genes in Escherichia coli. J. Bacteriol. 179:7671-7678.

van der Ploeg, J. R., Cummings, N. J., Leisinger, T., and Connerton, I. F. 1998. Bacillus subtilis genes for the utilization of sulfur from aliphatic sulfonates. Microbiology 144:2555-2561.

van der Ploeg, J., Eichhorn, E., and Leisinger, T. 2001. Sulfonate-sulfur metabolism and its regulation in Escherichia coli. Arch. Microbiol. 176:1-8.

Vermeij, P., and Kertesz, M. A. 1999. Pathways of assimilative sulfur metabolism in Pseudomonas putida. J. Bacteriol. 181:5833-5837.

Wilson, J., and Kappler, U. 2009. Sulfite oxidation in Sinorhizobium meliloti. Biochim. Biophys. Acta 1787:1516-1525.

\section{AUTHOR-RECOMMENDED INTERNET RESOURCE}

Rhizobase website: genome.kazusa.or.jp/rhizobase 